\title{
STRATEGI PEMBANGUNAN ISLAM DI ACEH PASCA TSUNAMI MENUJU TERWUJUDNYA MASYARAKAT RELIGIUS
}

\author{
Sukiman \\ Fakultas Ushuluddin IAIN Sumatera Utara Medan \\ Jl. Willem Iskandar Pasar V Medan Estate, 20371 \\ e-mail: winsukiman@yahoo.com
}

\begin{abstract}
Abstrak: Sejak Indonesia merdeka hingga masa Reformasi, Aceh senantiasa mengalami pasang surut. Sepanjang sejarah tersebut, konflik, baik secara vertikal masyarakat dengan Pemerintah RI, maupun secara horizontal sesama masyarakatnya, selalu saja terjadi. Terjadinya bencana tsunami 2004 menambah penderitaan rakyat Aceh, namun sekaligus memberi hikmah tentang pentingnya membangun Aceh kembali dalam bingkai wawasan keislaman dan keindonesiaan. Pasca tsunami, pembangunan kembali Aceh menjadi topik yang banyak dibicarakan. Dalam konteks itu, penulis memaparkan strategi rekonstruksi Aceh yang bertumpu pada pertama, membuat buku panduan pengamalan Syariat Islam untuk mayarakat dalam kehidupan sehari-hari. Kedua, membuat perencanaan pembangunan dengan menggunakan prinsip-prinsip pembangunan Islam. Ketiga, mewujudkan pemerintahan yang bersih dan berwibawa.
\end{abstract}

\begin{abstract}
Islamic Development Strategy in Post-Tsunami Aceh towards Establishing Religious Society. Since Indonesian independence to the reformation era the development in Aceh has undergone changable rise and fall. In such history long-lasting conflict, be it vertically between the people and the government of the Republic of Indonesia or horizontally amongst the society had repeatedly happened. The tsunami of 2004 put the burden of Acehnese people even heavier, but at the same time it throw light into the importance of reconstructing Aceh in the framework of Islamic and Indonesian ways of life. In the post tsunami, the reconstruction of Aceh has become the most discussed topic. In this context, this essay extensively discusses the strategy of reconstruction in Aceh which mainly focus on: First, writing the blueprint of the Islamic teaching experience that should become as a guideline for peoples' daily lives. Second, planning development program based on the Islamic development principles. Third, establishing an accountable and good governance.
\end{abstract}

Kata Kunci: pembangunan Islam, Aceh, masyarakat religius 


\section{Pendahuluan}

Pembangunan Aceh sejak Indonesia merdeka sampai zaman Reformasi belum berhasil dengan baik. Berbagai ekspresi atas ketidakpuasan masyarakat terhadap proses pembangunan ini telah memunculkan fenomena destruktif. Hal itu, ditandai dengan munculnya berbagai protes melalui gerakan rakyat seperti Darul Islam/Tentara Islam Indonesia, Aceh Merdeka, dan terakhir, Gerakan Aceh Merdeka, sehingga menimbulkan konflik berkelanjutan dan dapat mengganggu pembangunan Aceh. Jika pembangunan tidak berjalan dengan baik, maka permasalahan rakyat Aceh akan semakin sulit, karena suasana yang bergejolak dapat menciptakan kesengsaraan, penderitaan, kemiskinan, ketakutan, kelaparan sehingga keadaan Aceh semakin tidak kondusif. Dalam keadaan seperti inilah, datang pula bencana dahsyat berupa tsunami yang meluluh lantakkan pembangunan Aceh.

Pasca tsunami, semua elemen masyarakat Aceh harus menyadari bahwa bencana besar ini mengisyaratkan perlunya pembangunan masyarakat yang Islami sesuai dengan posisi Aceh sebagai serambi Makkah dan satu-satunya daerah yang melaksanakan Syariat Islam sebagai pedoman hidup negara dan masyarakat. Ajaran Islam yang kâffah jika diamalkan dan dijadikan pedoman dalam kehidupan sehari, termasuk sebagai asas pembangunan, maka akan meraih tujuan pembangunan untuk kesejahteraan umat di dunia dan akhirat.

Rakyat Aceh yang menduduki salah satu provinsi paling Barat Sumatera ini, dominan menganut agama Islam, karena mereka telah memberlakukan "Syariat Islam" sebagai dasar kehidupan sehari-harinya. Islam yang telah dianut oleh masyarakat Aceh ini telah berakar sejak Islam masuk ke wilayah Aceh sekitar abad ketiga belas di pesisir Aceh Utara Perlak. ${ }^{1}$ Bahkan cacatan sejarah kawasan ini merupakan kerajaan Islam di Asia Tenggara sejak abad enam belas dan tujuh belas Masehi. ${ }^{2}$ Sejak itulah Islam terus berkembang sehingga Aceh telah pula menjadi pusat Islam Asia Tenggara. Dengan mengamalkan Islam secara kaffah (sempurna), Aceh terus mencapai kejayaan terutama pada masa kesultanan Aceh dari tahun 1514-1912 M. Kejayaan Aceh ini diraih karena pemimpin mereka mampu membangun masyarakatnya sebagai umat yang saleh, struktur pemerintah Islam yang jelas, ${ }^{3}$

${ }^{1}$ Sehingga menjadi kerajaan Islam Samudra Pasai, bahkan dalam kitab "Izha a-Haqq fi Silsilah Raja Perlak" yang ditemukan baru-baru ini dapat dipercaya, sejak abad kesembilan di Perlak sudah muncul Kerajaan Islam. Kitab ini ditulis oleh seorang penulis sejarah bernama Abu Ishaq al-Makrani al-Fasi. Ia berasal dari keluarga Mekran Baluchistan (Pakistan Barat) yang sejak lama tinggal di Pasai. Dalam kitab itu dikatakan, kerajaan Perlak didirikan pada tahun $225 \mathrm{H} / 847$ M, dan diperintah berturut-turut oleh delapan Sultan. Taufik Abdullah, et al., Agama dan Perubahan Sosial (Jakarta: Rajawali, 2002), h. 12.

${ }^{2}$ Ahmad Daudy, Allah dan Manusia dalam Konsep Syekh Nuruddin ar-Raniry (Jakarta: Rajawali Press, 1983), h. 6.

${ }^{3}$ Dalam struktur kesultanan Aceh terdapat dua kelompok aparat yang melaksanakan tugasnya sesuai dengan batas dan wewenang masing-masing. Pertama. Fungsionaris masalah dunia (adat) 1. Sultan dalam unit kesultanan. 2. Ulebalang dalam unit Nanggro. 3. Panglima sagoe dalam unit sagi. 4. Kepala mukmin dalam unit mukim. 5. Keucik dalam unit meunasah atau gampung. Kedua. Fungsionaris dalam masalah agama (syariat) yaitu: 1. Kadi Malik 'adil pendamping sultan 2. Kadi 
integrasi Islam dengan adat istiadat Aceh, ${ }^{4}$ dan memiliki pendidikan yang berkualitas sehingga Aceh telah menjadi pusat pendidikan dan pengajaran di Asia Tenggara dengan memiliki berbagai bidang ilmu ${ }^{5}$, sehingga Islam telah menjadi pedoman hidup bernegara, bermasyarakat, berekonomi, dan berbudaya. Cita-cita itulah yang terus menerus diperjuangkan oleh rakyat Aceh sampai kini termasuk pasca tsunami. Tulisan ini bertujuan untuk mengedepankan ide tentang strategi membangun masyarakat Aceh yang religius.

\section{Kejayaan Islam Aceh Masa Lalu}

Daerah Aceh, ${ }^{6}$ sebagai pintu gerbang lintas perdagangan, pendidikan dan kebudayaan yang telah berlangsung cukup lama, yaitu awal abad ke-7, Aceh telah menjadi tempat persinggahan para pedagang Cina, Eropa, India dan Arab. Aceh sangat terkenal masa Kerajaan Islam pertama di Asia Tenggara7 yaitu kerajaan Islam Pasai yang dibangun oleh Sultan Ali Mughayat Syah dengan ibu kotanya Banda Aceh Darussalam. Kerajaan Aceh mencapai puncak kejayaannya awal abad ke-17 pada masa pemerintahan Sultan Iskandar Muda, dengan berbagai kemajuan yang telah dicapai baik dalam aspek kerjasama ekonomi, politik, militer, dan kebudayaan. ${ }^{8}$ Kemajuan kerajaan ini dapat dibuktikan dengan istana yang indah, luas dan besar, ${ }^{9}$ sebagai pusat administrasi negara. Istana memiliki areal

ulebalang pendamping ulebalang. 3. Imum mukim pendamping kepala mukim. 4. Teungku meunasah pada unit meunasah atau gampung, lihat Taufik Abdullah, Agama dan Perubahan Sosial, h. 220.

${ }^{4}$ Proses pelaksanaan Islam di Aceh menyesuaikan praktik agama dengan tradisi atau adat istiadat itu tercermin dalam ungkapan Aceh yang sangat populer, yaitu: "Adat ngon hukom hanjeut cree zat ngon sifeut" artinya: adat dan syariat Islam tidak dapat dipisahkan, seperti zat dengan sifat. Di sini kaedah Islam sudah merupakan bagian dari adat istiadat Aceh. Dalam masyarakat Aceh terdapat dua konsepsi: Pertama. Adah Allah yang hana ubah siumu masa (ketentuan Allah SWT.) yang tidak berubah sepanjang masa. Kedua. Adah' al-Muhakkamah (adat kebiasaan masyarakat berdasarkan masyarakat Islam. Ibid, h. 219.

${ }^{5}$ Di antaranya ialah Darul Tafsir wa al-Hadith (Fakultas Tafsir Dan Hadis), Darul Thib (Fakultas Kedokteran), Darul Kimia (Fakultas Kimia), Darul Siyasah (Fakultas Ilmu Politik), Darul Hasanah Baitul Mal (Fakultas Ilmu Perbendaharaan dan Keuangan Negara) dan lain-lain. Begitulah Aceh pada abad 16 telah tampil sebagai gudang ilmu di Asia Tenggara, berduyun-duyun para ilmuan datang ke Aceh untuk menyumbang ilmu ataupun sebaliknya datang menuntut ilmu.

${ }^{6}$ Aceh berasal dari kata aca yang artinya saudara perempuan, konon berasal dari kata $b a$ 's $a$, semacam pohon beringin yang besar, inilah yang mungkin mengandung makna keindahan. Lihat, Abu Bakar Aceh tentang nama Aceh dalam Ismail Sunni (ed.), Bunga Rampai Tentang Aceh (Jakarta: Bentara Karya Aksara, t.t.)

${ }^{7}$ Kerajaan ini ialah Kerajaan Islam Pereulak di Pasai. Kerajaan ini tumbuh dan berkembang yang umumnya diterima para ahli sejarah sebagai kerajaan Islam pertama di Asia Tenggara, yaitu sejak abad ke-13 sampai akhir abad ke-16, pelayaran dan perdagangan yang dilakukan orang Muslim Arab, Irak, India, dan Srilangka. Taufik Abdullah et al., Ensiklopedi Tematik Dunia Islam (Jakarta: Ichtiar Baru van Hoeve, 2002), h. 12.

${ }^{8}$ Al-Chaidar, Gerakan Aceh Merdeka (Jakarta: Penebar Buku Madani Press, 1995), h. 27.

${ }^{9}$ Menurut satu versi, bangunannya sama seperti kebanyakan rumah terbuat dari kayu, bedanya hanya besar dan tinggi. Untuk sampai ke istana, setiap mengantar tamu, terlebih dahulu melalui tiga halaman yang cukup luas. Istana ini dihiasi dengan kain-kain bersulam emas. Ibid., h. 29. 
yang luas, dilindungi parit besar sekeliling antara 25-30 kaki didinding batu setinggi 1020 kaki. Di depan istana terdapat sungai mengalir, airnya jernih, memiliki empat buah pintu gerbang dan empat menara tinggi serta lapangan luas sebagai alun-alun. Pengawal sultan terdiri dari 3000 prajurit, 500 pegawai yang langsung mengurusi istana sultan dan masih terdapat 1500 hamba sahaya sultan. ${ }^{10}$

Kemajuan dalam bidang agama, pendidikan, dan ilmu pengetahuan cukup signifikan, di antaranya sultan telah membangun Masjid Baiturrahman. ${ }^{11}$ Serta berdirinya pesantrenpesantren (dayah) baik tingkat dasar, menengah, dan atas sebagai tempat pembinaan kader ulama. ${ }^{12}$ Para alumni pesantren ini kemudian dapat melanjutkan pelajaran mereka ke universitas Baiturrahman Banda Aceh yang memiliki delapan belas fakultas. ${ }^{13}$ Para lulusan dari dayah dan universitas ini telah dapat dirasakan oleh masyarakat Aceh, munculnya para ulama dan cendikiawan dengan berbagai keahlian, sehingga rakyat dapat membaca, berhitung, penggemar sastra, ahli pertukangan besi, tembaga, dan pembuatan kapal serta keahlian yang mengagumkan. ${ }^{14}$ Kemajuan yang telah dicapai masa itu ialah bidang militer, ${ }^{15}$ perdagangan, ${ }^{16}$ dan tata kota. ${ }^{17}$

Keberhasilan-keberhasilan yang dicapai Kerajaan Islam Darussalam, diperkirakan karena rakyat dan pihak kerajaan serta aparatur kerajaan komitmen dengan ajaran Islam serta menjadikan Islam sebagai asas pembangunan. Karena itu, dibuktikan berdasarkan adanya Qanun al-Asyi (perundang-undangan Aceh), institusi dan organisasi diatur berdasakan

${ }^{10}$ Muhammad Said, Aceh Sepanjang Abad (Medan: Waspada, 1990), h. 303.

${ }^{11}$ Meskipun Masjid ini terbakar, tetapi cikal bakal Masjid Baiturrahman, walaupun telah dipugar beberapa kali, tetap merupakan ide dari Sultan Iskandar Muda. Ibid., h. 3.

${ }^{12}$ Pesantren tersebut ialah Dayah Cot Kala, Dayah Lam Birah, Dayah Cot Ceubek, Dayah Blang Prie Geudong Pase, Dayah Blang Me, Dayah Simpang Kalam Singkil, Dayah Al-Fansuri, Dayah Rumpet, Dayah Blang di Tiro. Lihat A. Hasjmy, 50 Tahun Aceh Membangun (Banda Aceh: Majelis Ulama Daerah Istimewa Aceh, 1995), h. 8.

${ }^{13}$ Fakultasnya ialah Dâr al-Tafsîr Wa al-Hadits, Dâr al-Thib (Fakultas Kedokteran), Dâr alKimia, Dâr al-Tarîkh, Dâr al-Hisab, Ilmu Pasti, Dâr al-Syiasah (Fakultas Politik), Dâr al-Aql (Fakultas Ilmu Akal), Dâr al- $\underline{\text { Hakam }}$ (Fakultas Hukum), Dâr al-Falsafah, Dâr al-Kalam (Fakultas Ilmu Kalam/ Tauhid), Fakulti Wizarah (Pemerintahan), Dâr al-Khazanah Bait al-Mâl (Fakultas Bendahara Negara), Dâr al-Ardh (Fakultas Pertambangan), Dâr al-Nahw (Fakultas Bahasa Arab), Dâr alMazhib (Fakultas Perbandingan Agama), Dâr al- $\underline{H}$ arb (Fakultas Militer). Ibid., h. 9-10.

${ }^{14}$ Muhammad Said, Aceh Sepanjang Abad, h. 309.

${ }^{15}$ Telah berhasil memiliki angkatan perang baik infantri dan terutama gajah. Kapal perang seukuran 120 kaki dapat membawa 700-800 tentara. Ibid., h. 310.

${ }^{16}$ Aceh telah menjadi kota perdagangan yang maju, di mana pada tahun 1573 M Kerajaan Darussalam telah membuka hubungan luar negeri dan telah memiliki duta besar antara lain India, Paris, Turki, Tiongkok. Al-Chaidar, Gerakan Aceh Merdeka, h. 29.

${ }^{17}$ Kota Banda Aceh telah menjadi kota metropolitan, indah, luas, dan teratur. Menurut Denys Combard, bahwa kota ini luasnya 2 mil, jumlah penduduk 7000-8000 jiwa, terdapat pusat aktivitas umum, pasar, dan masjid. Terdapat 3 buah pasar untuk aktivitas transaksi jual beli perdagangan dalam dan luar negeri. Denys Lombard, Kerajaan Aceh Zaman Iskandar Muda (Jakarta: Balai Pustaka, 1986), h. 60. 
Islam yang bersumber dari al-Qur'an, al-Hadis, Ijma' dan Qiyas. ${ }^{18}$ Sebab itu, seluruh penyelenggaraan kerajaan mulai dari Raja, Wazir, serta kepala-kepala kampung (geucik), balai-balai kerajaan baru dapat diangkat setelah menguasai ilmu dunia dan ilmu akhirat, kuat iman dan menjalankan syariat Islam, saleh, demikian disebutkan dalam salah satu qanun. Tentang hal ini, dicantumkan bahwa jika raja adil, maka dia harus memiliki ilmu dunia dan akhirat, memiliki iman yang kuat, takwa kepada Allah, Rasul Allah, serta mengerjakan syariat Nabi. Di samping itu harus beramal saleh berbuat adil pada seluruh rakyat, mampu melawan hawa nafsu syaitan dan mampu mensejahterakan rakyat sehingga selamat dan bahagia dunia dan akhirat. ${ }^{19}$

\section{Keadaan Aceh Pra Tsunami}

Rakyat Aceh sejak zaman pemerintahan Soekarno, belum banyak mengalami perubahan signifikan. Tidak ditepatinya janji memberikan otonomi khusus Islam, bahkan sebaliknya membubarkan Provinsi Aceh bergabung dengan Provinsi Sumatera Utara, telah memunculkan pemberontakan DI (Darul Islam), Tentara Islam Indonesia (TII) Muhammad Daud Bereueh. Demikian pula pada masa Soeharto yang memberlakukan Aceh sebagai Daerah Operasi Militer (DOM) dan telah mengeksploitasi hasil bumi untuk kepentingan Pusat tanpa memberikan hasil yang layak kepada Aceh. ${ }^{20}$ Penerapan DOM di Aceh menciptakan kesenjangan sosial yang luar biasa mengakibatkan banyak korban nyawa orang-orang yang tidak berdosa dengan cara penyiksaan, pembunuhan, pemerkosaan, dan perusakan. ${ }^{21}$ Pada masa Reformasi, zaman Abdurrahman Wahid yang memberikan peluang referendum, tetapi tidak jadi dilaksanakan, sehingga hal itu sangat menyulut kebebasan rakyat Aceh. Padahal masa itu utusan rakyat Aceh yang dipimpin oleh Gubenur Aceh Syamsuddin Mahmud bermohon kepada Presiden agar di Aceh ditegakkan hukum, meminta amnesti terhadap narapidana saparatis, undang-undang keistimewaan Aceh, Pemerintah Aceh mengelola harta kekayaan Daerah. ${ }^{22}$ Tidak satu pun tuntutan ini dipenuhi, bahkan sebaliknya Pemerintah Pusat masih memberlakukan Darurat Militer di Aceh.

Pemberlakuan Darurat Militer pertama mengklaim telah menangkap 2.878 anggota Gerakan Aceh Merdeka (GAM) yang menyerahkan diri 1.798. Demikian juga pada Darurat Militer II diperkirakan telah menangkap 6.622 orang. ${ }^{23}$ Begitulah keadaan Aceh semakin tidak menentu, terjadinya konflik yang sangat mempengaruhi kehidupan sosial ekonomi

\footnotetext{
${ }^{18}$ Al-Chaidar, Gerakan Aceh Merdeka, h. 34.

${ }^{19}$ Hasjmy, 50 Tahun Aceh Membangun, h. 18.

${ }^{20}$ Al-Chaidar, Gerakan Aceh Merdeka, h. 150.

${ }^{21}$ Menurut catatan Al-Chaidar, korban diperkirakan 38.000.5000 jiwa hilang, tidak kurang dari 51 kasus kekerasan, 21 kasus kisah getir umat Islam. Ibid., h. 112-148.

${ }^{22}$ A. Kadir Suyb, Dinamika Konflik dalam Transmisi Demokrasi (Jakarta: LKBN Antara, 2004),

${ }^{23} I b i d .$, h. 6.
} h. 51 . 
masyarakat, bahkan rakyat menjadi takut melakukan aktivitas di perkebunan, pekerjaan menjadi telantar, rakyat jadi miskin, pendidikan tertinggal, terakhir munculnya kejahatan di mana-mana.

Ada dua hal penting yang menjadi perhatian publik menjelang terjadinya tsunami. Pertama, realisasi proses damai mulai dari titik perjanjian jeda kemanusiaan Aceh yang telah disepakati di Geneva tanggal 12 Mei hingga Darurat Sipil yang kembali (terpaksa) disambung. Proses damai ini bukannya berhasil, malah menghasilkan sejumlah side effects berupa maksiat. Kedua, proses pengadilan terhadap Gubenur Aceh Abdullah Puteh yang ditahan di Polda Metro Jaya Jakarta dalam kasus korupsi pembelian helikopter dari Rusia untuk Kerajaan Daerah Nanggroe Aceh Darussulam. ${ }^{24}$ Dengan demikian telah terjadi krisis akhlak baik di kalangan pejabat daerah, maupun maksiat dalam masyarakat, sehingga konflik ini terus berkesinambungan.

Dalam keadaan yang mencekam ini, masyarakat Aceh dihadapkan kepada dua persoalan sekaligus, yaitu kekerasan militer dan maksiat, ${ }^{25}$ sehingga banyak kalangan secara bisik-bisik menyatakan bahawa Aceh bukan lagi Serambi Makkah tetapi telah menjadi daerah kejahatan, meskipun mungkin dibawa oleh pendatang ke Aceh, sehingga keadaan di sepanjang pantai Aceh banyak sekali tempat-tempat pelacuran, dan kemaksiatan lainnya. ${ }^{26}$ Dalam suasana yang memburuk ini, rakyat Aceh mengalami musibah gempa bumi dan tsunami. $^{27}$

\section{Tsunami Telah Merusak Asas Pembangunan di Aceh}

Pada tanggal 26 Desember 2004 terjadilah gempa bumi berkekuatan 8,9 skala Richter, yang sesaat kemudian mendatangkan tsunami dahsyat dengan kecepatan $500 \mathrm{~km}$ perjam, bahkan menurut Menteri Riset dan Teknologi Indonesia, tsunami dapat mencapai 7001000 Kilometer perjam. Bencana besar ini merupakan bencana keempat terbesar di dunia sejak tahun $1900 \mathrm{M}$, menewaskan 228.429 orang dan menghilangkan 92.234 orang. ${ }^{28}$

Akibat tsunami telah menghancurkan beberapa kota di Aceh seperti Banda Aceh, terlihat bagaikan kawasan tambak ikan. Bangunan kantor Gubenur ikut rusak, swalayan, pasar raya Aceh rubuh, rumah hancur, dan tidak ada satupun di antara dataran rendah di sepanjang jalan Banda Aceh sampai Meulaboh yang selamat dari terjangan tsunami. ${ }^{29}$

\footnotetext{
${ }^{24}$ Apridar, Tsunami Azab Atau Bencana (Jakarta: Pustaka Al-Kautsar, 2005), h. 1.

${ }^{25}$ Ibid., h. 4.

${ }^{26} I b i d .$, h. 5.

${ }^{27}$ Menurut Asaari Muhammad, bahwa tsunami membawa pesan dari Allah SWT., yaitu: bahwa Tuhan menjalankan sebab akibat atau sunnah-Nya, ada yang umum dan ada yang khusus. Lihat Asaari Muhammad dan Khatijah Am, Tsunami Pembawa Mesej dari Tuhan (Selangor: Minda

${ }^{28}$ Media Fakta (29 Desember 2004).

${ }^{29}$ Kompas (10 Januari 2005).
} Ikhwan, 2005), h. 8-10. 
Tsunami dahsyat ini telah pula melunturkan dimensi pembangunan yaitu keperluan dasar, yang menurut al-Syâthibî keperluan dasar manusia itu ialah sesuai dengan prinsip maqâshid al-syariah yang meliputi al-dîn (agama), al-Nafs (jiwa), al-aql (ilmu), al-mâl (harta) dan al-'ardh (harga diri). ${ }^{30}$ Bidang agama dan keyakinan, mulai luntur akibat tsunami, hal ini dimungkinkan karena adanya anggapan sebagian orang bahwa Allah SWT. tidak mengasihi orang Aceh karena satu-satunya Provinsi di Indonesia yang menerapkan syariat Islam, tetapi Islam sebagai simbol, masyarakatnya belum mengamalkan Islam secara maksimal, sehingga dikirimlah ujian berupa bencana alam dahsyat oleh Allah SWT. ${ }^{31}$

Mengapa Aceh yang mengamalkan Syariat Islam sebagai pedoman hidup, daerah yang memilki ulama dan mujahid dan penduduknya semua Muslim justru mendapat bencana? Pertanyaan-pertanyaan itu masing-masing muncul dari hati dan pikiran sebahagian rakyat Aceh, sebagai sesuatu yang kurang menerima takdir Allah SWT. dan mungkin mereka merasa bahwa Allah tidak menyayangi orang Aceh yang tetap menjalankan syariat-Nya. Ungkapan ini sebagai sebuah isyarat menipis dan terkikisnya akidah umat dan mungkin akan semakin jauh dari dîn al-Islâm.

Demikian pula pada nafs (jiwa) yang telah tewas akibat tsunami sampai ratusan ribu penduduk yang meninggal dunia, ${ }^{32}$ walau bagi mereka yang masih hidup telah melihat bagaimana dahsyatnya tsunami yang menimbulkan rasa ketakutan, kekhawatiran dan mungkin ada yang mengalami kegoncangan jiwa, yang memerlukan pembinaan mental. Hilang dan hancurnya sejumlah material dan harta yang mencapai 41.401 triliun rupiah. ${ }^{33}$ Demikian pula telah menghancurkan fasilitas pendidikan di antaranya gedung-gedung sekolah dasar 639 unit, sekolah menengah 149 unit, sekolah menengah 358 unit, gedung universitas 5 unit. ${ }^{34}$ Kerusakan ini dapat menghambat proses pendidikan bagi kecerdasan rakyat Aceh. Tidak kalah pentingnya ialah hancurnya "harga diri," karena telah menjadi rakyat yang dhu'afa menerima bantuan dari berbagai penjuru dunia termasuk dari negara Barat yang non Muslim dan mungkin juga akan meruntuhkan keimanan dan akhlak rakyat Aceh.

${ }^{30}$ Al-Syâthibî, Al-Muwafaqat fì Ushûl al-Ahkkam (Beirut: Dâr Fikri, t.t.), h. 3; Muhammad Abû Zahrah, Ushûl al-Fiqh (Mesir: Dâr al-Fikr al-'Arabî, 1958), h. 5.

${ }^{31}$ Azman Ismail, Hikmah Tsunami di Baiturrahman (Banda Aceh: Yayasan Baiturrahman, 2005), h. 106.

${ }^{32}$ Data korban seluruhnya masih simpang siur, tetapi data yang diumumkan pada 5 Februari 2005 jumlah korban tercatat 112.878-120.182 orang. Prabudi Said, Berita Peristiwa 60 Tahun Waspada (Medan: Prakarsa Abadi Press, 2005), h. 165.

${ }^{33}$ Team Taskforce Badan Perencanaan Pembangunan Nasional, Blue Print Rekontruksi Aceh, (Banda Aceh: Universitas Syiah Kuala, 2005), h. 29.

${ }^{34}$ Ibid., h. 90. 


\section{Strategi Membangun Aceh Menuju Masyarakat yang Religius}

Aceh sejak berdirinya sebagai Kerajaan Islam telah diberi nama "Darussalam" (negeri sejahtera) dan "Serambi Makkah", 35 itu artinya bahwa rakyat Aceh dapat meraih kedamaian dan kesejahteraan manakala melaksanakan Syariat Islam secara kâffah. ${ }^{36}$ Pelaksaan syariat Islam Aceh masa kini belum sampai kepada tahap kâffah, baru pada tahap awal keislaman, seperti diucapkan oleh Gubenur Aceh ketika itu H. Azwar Abubakar, "Musibah gempa dan tsunami sebagai peringatan dan pembelajaran dari Allah SWT. sebagai peringatan mengharuskan kita melakukan introspeksi terhadap iman dan aktualisasinya dalam bentuk amal kita selama ini sebagai sebuah daerah yang telah mengisytiharkan diri untuk melaksakan syariat Islam, apakah kita sudah menjalankannya dengan sungguhsungguh. Atau jangan-jangan masih setengah-setengah hati dengan Syariat Allah SWT. dan sebagai pembelajaran, hendaknya kita boleh hidup cerdas dan bermartabat". ${ }^{37}$

Mengamalkan Islam secara kâffah, berarti telah pula menjadi umat rabbanî. Seperti yang digambarkan oleh Allah SWT. dalam firman-Nya pada Q.S. Ibrâhîm/14: 24-25:

Tidakkah kamu perhatikan bagaimana Allah telah membuat perumpamaan kalimat yang baik seperti pohon yang baik, akarnya teguh dan cabangnya (menjulang) ke langit, pohon itu memberikan buahnya pada setiap musim dengan seizin Tuhannya. Allah membuat perumpamaanperumpamaan itu untuk manusia supaya mereka selalu ingat.

Umat yang rabbanî ialah umat yang saleh mengamalkan Islam dengan kâffah (menyeluruh) dalam aspek kehidupan. Firman Allah dalam Q.S. Âli 'Imrân/3: 79 terdapat kata "kunu rabbaniyîn" (kamu menjadi umat rabbanî) yang menurut Sayyid Qutb: "Sesungguhnya Nabi telah meyakini bahwa ia sebagai hamba Allah yang Maha Esa dan Maha Mendidik yang menjadi tujuan hidup untuk beribadah dan tujuan mengabdi. Karena itu, tidak mungkin seorang hamba mengatakan sebagai Tuhan yang mengatur dan disembah manusia. Sebaliknya mereka katakan yaitu dibangsakan kepada Allah yang Maha Mendidik, Memelihara. Dia sebagai tujuan beribadah, pengabdian seorang hamba, jadikanlah Dia sebagai jalan kehidupan". ${ }^{8}$

Demikian pula M. Quraish Shihab, mengatakan bahwa umat rabbanî ialah semua

${ }^{35}$ Ada beberapa versi cerita rakyat tentang sebab pemberian gelar Serambi Makkah bagi Aceh, salah satu di antaranya ialah ketika Sultan Malikul Saleh dinobatkan dengan memakai pakaian kerajaan anugrah dari Makkah, dan acara penabalan secara Arab, sehingga gelarannya pun disebut "Syah A'lam Zillu Ilai fi al-'Alam". Lihat Muhammad Said, Aceh Sepanjang Abad, h. 85. Walaupun ada juga cerita di masa lalu orang Muslim Indonesia yang menunaikan ibadah Haji harus melalui Aceh menggunakan kapal Laut di saat pesawat terbang belum digunakan sebagai alat transportasi membawa jamaah haji.

${ }^{36}$ Islam kâffah di Aceh ialah, Islam yang diamalkan secara menyeluruh meliputi akidah, syariah, dan akhlak, serta mencakup bidang lain yang lebih luas seperti aspek ekonomi, pendidikan, politik, kesenian, olahraga, dan seterusnya. Alyasa Abu Bakar, Syariat Islam di Provinsi Nanggroe Aceh Darussalam, (Banda Aceh: t.p., 2006), h. 19.

${ }^{37}$ Ismail, Hikmah Tsunami di Baiturrahman, h. 106.

${ }^{38}$ Sayyid Quthb, Fî Zilâl al-Qur'ân (Kairo: Dâr al-Syurûq, 1992), h. 419. 
aktivitas, gerak dan langkah, niat dan ucapan kesemua itu sejalan dengan nilai-nilai yang dipesankan oleh Allah SWT. ${ }^{39}$ Untuk mewujudkan masyarakat Aceh yang rabbanî ini, diperlukan langkah-langkah strategis bagi pembangunan Aceh kembali pasca tsunami yaitu:

Pertama. Melaksanakan Islam secara kâffah. Mungkin saja Islam kaffah ini belum diketahui oleh sebagian rakyat Aceh, karena itu perlu dibuat buku pedoman dan disosialisasikan melalui aktivitas dakwah dan pendidikan ke tengah-tengah masyarakat. Karena Islam agama universal, Islam dapat menyelesaikan seluruh problematika masyarakat, Islam memberikan keadilan sosial, adil dalam hukum, adil dalam material, kesempatan, dan adil dalam pembalasan. ${ }^{40}$ Selain itu, perlu diketahui oleh seluruh lapisan masyarakat Aceh tentang keunggulan Islam, yang menurut Sayyid Qutb ada tujuh Tasawur (konsep) Islam yaitu: (1) al-Rabbaniyah, ${ }^{41}$ berupa akidah ${ }^{42}$ wahyu dari Allah, (2) al-Tsubut ${ }^{43}$ (ketetapan) tentang nilai-nilai kebenaran dan tidak akan berubah, (3) al-Sumuliyah ${ }^{44}$ (menyeluruh), sifat manusia yang tunduk kepada keadaan dari segi masa dan tempat (4) Tawâzun ${ }^{45}$ (seimbang) untuk kepentingan dunia dan akhirat, sesuai antara perkataan dan amal (5) al-Ijabah ${ }^{46}$ (positif) antara hubungan manusia dengan Allah (6) al-Waqiah ${ }^{47}$ di mana Tuhan dapat menciptakan sesuatu dengan realitas, dan (7) al-Tauhît ${ }^{48}$ sebagai hakikat pokok dalam akidah Islam.

Keunggulan Islam meliputi akidah, ibadah, muamalah, akhlak, dan ilmu Islam lain yang perlu dibuat secara praktis, jika perlu dituangkan dalam bahasa Aceh dan disampaikan kepada seluruh lapisan masyarakat dan lewat pendidikan baik formal maupun informal. Menurut al-Qur'an bahwa orang yang beriman dan amal saleh, akan mendapatkan kehidupan yang mulia dan kesejahteraan baik di dunia maupun di akhirat, firman Allah dalam Q.S. al-Nahl/16: 97. Menurut al-Qur'an pula bahwa jika rakyat satu daerah atau negeri yang beriman dan bertakwa, niscaya Allah melimpahkan balasan berupa keberkatan dari langit dan bumi (Q.S. al-Ahzâb/33: 96).

Kedua. Merancang pembangunan berasaskan Islam. Selama ini rencana pembangunan di Aceh tetap menggunakan arahan dari Garis-Garis Besar Haluan Negara (GBHN), ${ }^{49}$

${ }^{39}$ M. Quraish Shihab, Tafsir Al-Misbah, vol. 2 (Jakarta: Lentera Hati, 2000), h. 125.

${ }^{40}$ Sayyid Quthb, Ma'rakah al-Islam wa Ra'simaliyat (Kairo: Dâr al-Syurûq, 1988), h. 36.

${ }^{41}$ Sayyid Quthb, Khasais al-Tasawwur al-Islâm wa Mukumatuh (Kairo: Dâr al-Syurûq, 1988), h. 430 .

${ }^{42}$ Tentang akidah atau tauhid lihat, Ismail Raji al-Faruqi, Tauhid: Its Implications for Thought and Life (Pensylvania: The International Institute of Islamic Toughts, 1982).

${ }^{43}$ Sayyid Quthb, Ma'rakah al-Islam, h. 72.

${ }^{44}$ Ibid., h. 91.

${ }^{45}$ Ibid., h. 114.

${ }^{46}$ Ibid., h. 146.

${ }^{47}$ Ibid., h. 162.

${ }^{48}$ Ibid., h. 182.

${ }^{49} \mathrm{GBHN}$ ini sudah dibuat sejak Orde Baru dengan sistematikanya ialah Pendahuluan, Pem- 
dan dijabarkan secara khusus dalam Rencana Umum Tahunan Daerah. ${ }^{50}$ Pasca tsunami ini telah dibuat beberapa rencana pembangunan, antara lain Blue Print Rekonstruksi Aceh ${ }^{51}$ Rencana Pembangunan Jangka Menengah (RPJM) Propinsi Nanggroe Aceh Darussalam 2007-2012 ${ }^{52}$ dan ada lagi rencana pembangunan khusus yang dibuat oleh Badan Rehabilitasi dan Rekonstruksi Aceh dan Nias.

Rencana pembangunan yang telah disebutkan di atas cukup baik, dan komprehensif, jika dapat dilaksanakan mungkin Aceh akan mencapai kemajuan. Tetapi sangat disayangkan bahwa rencana-rencana tersebut kurang menyentuh aspek spiritualitas dan amal shaleh umat Islam Aceh. Lebih mengedepankan pembangunan lazim, karena diukur dengan kuantitatas seperti peningkatan produktivitas, peningkatan pendapatan perkapita, peningkatan keluaran negara kasar, peningkatan kadar pertumbuhan dan peningkatan keuangan ${ }^{53}$ pembangunan lazim ini, lebih dekat kepada ide pembangunan model Barat yang menekankan pembangunan fisik material dan kemodernan. Rencana seperti ini mungkin akan dapat menjauhkan masyarakat Aceh dari ajaran Islam.

Untuk mewujudkan umat Islam Aceh yang rabbanî, sepatutnya sudah ada rencana pembangunan terpadu secara keseimbangan antara kepentingan dunia (materil fisik) dengan kepentingan akhirat (akidah-ibadah-akhlak). Rencana seperti itulah yang sekarang dikenal dengan Pembangunan Berteraskan Islam. Pakar pembangunan model ini, Muhammad Syukri Salleh merancang tujuh Prinsip Pembangunan Berteraskan Islam, yaitu: (1) Taswaur Islam sebagai akar pembangunan (2) Manusia sebagai pelaku pembangunan (3) Alam Roh, Alam Dunia, dan Alam Akhirat sebagai skala waktu pembangunan (4) Fardhu 'ain sebagai kerangka pembangunan (5) Ibadah sebagai kaedah pembangunan (6) Sumber daya alam sebagai peralatan pembangunan (7) Mardhatillah (keridhaan Allah) sebagai tujuan pembangunan. ${ }^{54}$

Ketujuh prinsip pembangunan Islam ini harus dimasukkan dalam satu bagian rancangan pembangunan Aceh. Di atas kerangka ini disusun program pembangunan Aceh untuk masa depan dalam berbagai aspek seperti pendidikan, ekonomi, politik, hukum,

bangunan Nasional, dan Pembangunan Lima Tahun, dapat dilihat dalam Ketetapan MPR II (1998) GBHN 1998-2003.

${ }^{50}$ Sistematikanya ialah, Pendahuluan, Tujuan Pembangunan Daerah, Sasaran Skala Prioritas dan Strategi Kebijaksanaan, Pemerintah Provinsi Daerah Istimewa Aceh, 1999.

${ }^{51}$ Rancang ini dibuat para pakar dalam pelbagai keahlian dari Universitas Syiah Kuala (UNSIYAH), Institut Pertanian Bogor (IPB), Institut Teknologi Bandung (ITB), dan Universitas Sumatera Utara (USU).

${ }^{52}$ Rancangan ini dibuat oleh Badan Perencanaan Pembangunan Daerah Provinsi Nanggroe Aceh Darussalam Tahun. 2007, yang isinya merupakan arahan dari GBHN untuk Aceh.

${ }^{53}$ Muhammad Syukri Salleh, Kearah Pengurusan Pembangunan Islam dalam Pengurusan Pembangunan Islam (Malaya: IDMP Pusat Pengajian Sains Kemasyarakatan USM, t.t.), h. 11.

${ }^{54}$ Uraian lengkap dapat dibaca dalam Muhammad Syukri Salleh, 7 Prinsip Pembangunan Berteraskan Islam (Kuala Lumpur: Zebra Editions, 2003). 
budaya, dan pembangunan material lainnya. Berkenaan dengan rencana pembangunan Islam, Allah SWT. berfirman dalam Q.S. al-Hasyr/59:

Hai orang-orang yang beriman, takutlah kamu kepada Allah dan hendaklah (tiap-tiap) orang memperhatikan apa yang diusahakannya untuk hari esok dan takutlah kapada Allah. Sungguh Allah Maha Mengetahui apa-apa yang kamu kerjakan.

Ketiga. Mewujudkan pemerintahan yang baik (Good Governance). Salah satu keunggulan Kerajaan Sultan Iskandar Muda ialah, melaksanakan ajaran Islam dengan sempurna, dan memberlakukan ajaran Islam kepada seluruh aparaturnya. Ada lima kaedah yang mesti dimiliki oleh Sultan. Pertama, raja menjaga perintah dan menjaga pada memerintahkan rakyat, mengatur negeri dan perintah kerajaan. Kedua, baik adabnya. Ketiga, baik akalnya. Keempat, adil. Kelima, berani, benar kata-katanya, dan ikhlas. ${ }^{55}$ Kelima prinsip itu dapat diwujudkan jika Sultan taat kepada ajaran Islam. Untuk mendapatkan aparatur kerajaan, qanun memerintahkan setiap orang ditempatkan dalam jabatan tertentu, mereka harus diuji kemampuan agamanya, melalui pemahaman fiqih empat mazhab dan terdapat institusi Majlis Mahkamah Agung ${ }^{56}$ yang bertugas untuk memutuskan suatu perkara yang berpedoman kepada mazhab Syâfiî̀, Malikî, Hanafî, dan Hambalî.

Di Aceh saat ini telah dilakukan seleksi pegawai negeri dan tes kemampuan penguasaan Islam bagi yang menduduki jabatan tertentu. Untuk melaksanakan itu, Dinas Syariat Islam harus membuat pedoman dan aturan pegawai negeri sesuai dengan syariat Islam, sehingga semua pegawai negeri sebagai pelaksana pembangunan memahami dan dapat melaksanakan 7 prinsip pembangunan berasaskan Islam yang telah dirancang oleh Badan Perencanaan Pembangunan Islam Aceh (BPPIA).

Selain itu, perlu dilakukan pembinaan ilmu keislaman seluruh pegawai negeri secara internal, yakni dilaksanakan oleh kantor Dinas Syariat Islam yang mencakup akidah, ibadah, muamalah, akhlak, dan manajemen kalbu. Selain itu, perlu dilakukan pendidikan dan latihan keislaman terhadap aparatur pemerintah dan mesti dilakukan evaluasi, sehingga akan terwujud pegawai yang berkualitas. Surat keterangan kelulusan itu akan menjadi bahan pertimbangan bagi kenaikan pangkat pegawai pemerintahan Aceh serta menjadi bahan bagi meluluskan pegawai tersebut untuk menduduki suatu posisi pekerjaan dan jabatan. Dengan begitu aparat negeri ini akan maju, kreatif, dinamis dan terhindar dari Korupsi, Kolusi dan Nepotisme (KKN).

Adapun secara eksternal, seseorang yang akan mengemban amanah untuk mengurusi urusan publik, diperlukan evaluasi yang dilakukan oleh masyarakat. Sebagai contoh, jika seseorang yang akan diangkat menjadi menteri suatu departemen, semestinya sebelum diangkat masyarakat diminta berpartisipasi untuk memberikan evaluasinya. Standarisasi

${ }^{55}$ Hasjmy 50 Tahun Aceh Membangun, h. 45-63.

${ }^{56}$ Sebagai institusi tertinggi dalam bidang hukum yang dipimpin oleh Qadhi Mahkamah Adil yang dibantu oleh 10 ulama fiqih, Al-Chaidar, Gerakan Aceh Merdeka, h. 38. 
evaluasinya adalah menyangkut, kapabilitas (berhubungan dengan kemampuan dalam bidang skill dan intelektual) dan integritasnya (berhubungan dengan perilaku dan akhlaknya). Bagi pihak pemerintah daerah, perlu membuat panitia penilaian yang sertai juga oleh mereka-mereka dari kalangan akademisi, ulama dan tokoh masyarakat. Dengan demikian akan menghasilkan pemimpin yang memiliki kualitas yang prima atau unggul. Dalam bahasa al-Qur'an disebut dengan al-Qawy al-Amîn. Sebagaimana disebut dalam Q.S. alQashshash/28: 26:

Salah seorang dari kedua wanita itu berkata: "ya bapakku ambillah ia sebagai orang yang bekerja (pada kita), karena sesungguhnya orang yang paling baik yang kamu ambil untuk bekerja (pada kita) ialah orang yang kuat lagi dapat dipercaya.

Al-Qawy al-Amîn adalah pemimpin yang handal ${ }^{57}$ sebagaimana telah diimplementasikan oleh Rasulullah SAW. dalam kehidupannya, yaitu memiliki lima sifat yang harus melekat dalam dirinya. Lima sifat itu adalah: Pertama. Shiddiq, menjaga martabat dengan integritas, dengan cirinya memiliki niat tulus, berpikir jernih, bicara benar, bersikap terpuji, dan perilaku teladan. Kedua. Amanah, terpercaya, dengan ciri siap bertanggung jawab, cepat tanggap, objektif, akurat dan disiplin. Ketiga. Tabligh, yaitu kasih sayang, transparan, membimbing, visioner, komunikatif memberdayakan. Keempat. Fathanah, profesional, semangat belajar berkelanjutan, cerdas, inovatif, terampil dan adil. Kelima. Istiqamah, memegang teguh komitmen, optimis, pantang menyerah, konsisten, dan percaya diri. Kendati gambaran kepemimpinan di atas adalah sesuatu yang sangat ideal, tetapi mesti diusahakan untuk mendapatkan tokoh atau sosok pemimpin sesuai kriteria di atas, atau paling tidak mendekati kriteria tersebut, sehingga apa yang diharapkan untuk mewujudkan masyarakat Aceh yang rabbanî akan terwujud.

\section{Penutup}

Uraian-uraian di atas memberikan deskripsi tentang strategi membangun Aceh pasca tsunami menuju masyarakat religius, setidaknya ada tiga langkah yaitu: melaksanakan Islam secara kâffah, merancang pembangunan berasaskan Islam, dan mewujudkan pemerintah yang baik (Good Governance). Ketiga langkah tersebut dapat diimplemtasikan jika didukung oleh kemauan yang kuat dari pihak masyarakat dan pemerintah yang ada di Aceh, kerjasama yang harmonis dan sinergis antara masyarakat dan pemerintah di Aceh, adanya kesiapan dan ketersediaan sumber daya manusia yang handal dalam berbagai bidang, dan dukungan serta bantuan pemerintah pusat di Jakarta. Apabila ketiga langkah tersebut dapat diimplementasikan, maka pintu harapan untuk terwujudnya masyarakat yang religius akan terbuka lebar. Masyarakat religius yang dimaksud adalah masyarakat

${ }^{57}$ Tentang hal ini perhatikan, Abû Nashr al-Farâbî, Kitab Ara' Ahl al-Madinah al-Fadhîlah (Beirut: Dâr al-Masyriq, 1976). 
yang dalam kehidupannya berasaskan nilai-nilai Ilahiyah dan kemanusiaan, yang pada akhirnya melahirkan kehidupan yang damai, harmonis, makmur, dan sejahtera, serta bahagia dunia dan akhirat.

\section{Pustaka Acuan}

Abdullah, Taufik (et al). Ensiklopedi Tematik Dunia Islam. Jakarta: Ichtiar Baru van Hoeve, 2002.

Abdullah, Taufik (et al). Agama dan Perubahan Sosial. Jakarta: Rajawali, 2002.

Al-Chaidar. Gerakan Aceh Merdeka. Jakarta: Penebar Buku Madani Perss, 1995.

Al-Farâbî, Abû Nashr. Kitab Ara' Ahl al-Madînah al-Fadhîlah. Beirut: Dâr al-Masyriq, 1976.

Abu Bakar, Alyasa. Syariat Islam di Provinsi Nanggroe Aceh Darussalam. Banda Aceh: Dinas Syariat Islam NAD, 2006.

Apridar. Tsunami Azab atau Bencana. Jakarta: Pustaka al-Kautsar, 2005.

Daudy, Ahmad. Allah dan Manusia Dalam Konsep Syekh Nuruddin ar-Raniry, Jakarta: Rajawali Press. 1983.

Al-Faruqi, Ismail Raji. Tauhid: Its Implications for Thoughtn Life. Pensylvania: The International Institute of Islamic Thoughts, 1982.

Hasjmy, A. 50 Tahun Aceh Membangun. Banda Aceh: Majelis Ulama Daerah Istimewa Aceh, 1995.

Ismail, Azman. Hikmah Tsunami di Baiturrahman. Banda Aceh: Yayasan Baiturrahman, 2005.

Kompas. 10 Januari 2005.

Lombard, Denys. Kerajaan Aceh Zaman Sultan Iskandar Muda. Jakarta: Balai Pustaka, 1986.

Media Fakta. 29 Desember 2004.

Muhammad, Asaari, dan Khatijah Am. Tsunami Membawa Mesej dari Tuhan. Selangor Darul Ehsan: Penerbit Minda Ikhwan, 2005.

Quthb, Sayyid. Fî Zhilal al-Qur'ân. Kairo: Dâr al-Syurûq, 1992.

Quthb, Sayyid. Ma'rakah al-Islam wa Ra'simaliyat. Kairo: Dâr al-Syurûq, 1988.

Quthb, Sayyid. Khasais al-Tasawwur al-Islâm wa Mukumatuh. Kairo: Dâr al-Syurûq, 1988.

Al-Syâtibî. Al-Muwafaqat fî Ushûl al-Ahkkam. Beirut: Dâr al-Fikr, t.t.

Suyb, A. Kadir, Dinamika Konflik dalam Transmisi Demokrasi. Jakarta: LKBN Antara, 2004.

Salleh, Muhammad Syukri. 7 Prinsip Pembangunan Berteraskan Islam. Kuala Lumpur: Zebra Editions, 2003.

Salleh, Muhammad Syukri. Kearah Pengurusan Pembangunan Islam dalam Pengurusan Pembangunan Islam. Malaya: IDMP Pusat Pengajian Sains Kemasyarakatan USM, t.t. 
MIQOT Vol. XXXVI No. 1 Januari-Juni 2012

Shihab, M. Quraish. Tafsir al-Misbah, Vol. II. Jakarta: Lentera Hati, 2000.

Said, Prabudi. Berita Peristiwa 60 Tahun Waspada. Medan: Prakarsa abadi Press, 2005.

Sunni, Ismail, (ed.). Bunga Rampai Tentang Aceh. Jakarta: Bentara Karya Aksara, t.t.

Said, Muhammad. Aceh Sepanjang Abad. Medan: Waspada, 1990.

Team Taskforce Badan Perencanaan Pembangunan Nasional. Blue Print Rekontruksi Aceh. Banda Aceh: Universitas Syiah Kuala, 2005.

Zahrah, Muhammad Abû. Ushûl al-Fiqh. Mesir: Dâr al-Fikr al-'Arâbî, 1958. 